\title{
Ponticaulis koreensis gen. nov., sp. nov., a new member of the family Hyphomonadaceae isolated from seawater
}

\author{
Hye Soon Kang and Soon Dong Lee \\ Department of Science Education, Cheju National University, Jeju 690-756, Republic of Korea
}

Correspondence

Soon Dong Lee

sdlee@cheju.ac.kr

\begin{abstract}
An obligately halophilic, stalked bacterium, designated strain GSW-23 ${ }^{\top}$, was isolated from seawater that had been collected on the coast of Jeju, Korea. Cells of the strain were characteristically Gram-negative, aerobic, chemo-organotrophic, non-budding, motile rods or vibrioids that possessed prosthecae and holdfasts. Multiplication occurred by means of binary fission. The major ubiquinone was Q-10. The dominant cellular fatty acids were summed feature 7 (one or more of $\mathrm{C}_{18: 1} \omega 9 c, \mathrm{C}_{18: 1} \omega 12 t$ and $\left.\mathrm{C}_{18: 1} \omega 7 c ; 37.1 \%\right), \mathrm{C}_{16: 0}(25.5 \%)$ and $\mathrm{C}_{18: 0}$ (14.1\%). The DNA G + C content was 53.3 mol\%. 16S rRNA gene sequence analyses showed that the organism was related to members of the family Hyphomonadaceae and formed a distinct clade between members of the genus Hyphomonas and Hirschia baltica DSM $5838^{\top}$. Strain GSW-23 ${ }^{\top}$ was most closely related to the genus Hyphomonas (92.5-93.9\% sequence similarity), but differed from members of the genus by reproduction by binary fission, some physiological properties (gelatin liquefaction and tolerance of $6 \% \mathrm{NaCl}$ ) and chemotaxonomic features (major fatty acids, major quinones and DNA G $+C$ content). The other genera of the family can be readily differentiated from the isolate by a battery of cultural, physiological and chemotaxonomic characteristics. On the basis of the phenotypic and phylogenetic data presented here, strain GSW-23 ${ }^{\top}$ represents a novel genus and species in the family Hyphomonadaceae, for which the name Ponticaulis koreensis gen. nov., sp. nov. is proposed. The type strain of Ponticaulis koreensis is strain GSW-23 $3^{\top}\left(=\right.$ KCTC $\left.22146^{\top}=\mathrm{DSM} 19734^{\top}=\mathrm{JCM} 14975^{\top}\right)$.
\end{abstract}

The family Hyphomonadaceae was recently defined by Lee et al. (2005) and encompasses Gram-negative, prosthecate bacteria that have mainly been isolated from marine environments. The family currently includes Hyphomonas (Pongratz, 1957), Hirschia (Schlesner et al., 1990), Maricaulis (Abraham et al., 1999), Oceanicaulis (Strömpl et al., 2003) and Robiginitomaculum (Lee et al., 2007). In this study, we describe the isolation, classification and identification of a stalked bacterium from beach seawater by using a polyphasic approach.

Strain GSW $-23^{\mathrm{T}}$ was isolated from seawater collected from Kymnyeong Beach on the island of Jeju, Republic of Korea. For the isolation of marine bacteria, the seawater sample was filtered through a membrane filter $(0.45 \mu \mathrm{m}$ pore size $)$ and was then transferred directly onto marine agar (MA; Difco). Following incubation at $30{ }^{\circ} \mathrm{C}$ for 8 days, a colony on plates was selectively taken and subcultured on MA. The

The GenBank/EMBL/DDBJ accession number of the 16S rRNA gene sequence of strain GSW-23 ${ }^{\top}$ is FM202497.

A supplementary table showing the cellular fatty acid compositions of strain GSW-23 ${ }^{\top}$ and related species is available with the online version of this paper. pure culture was stored at -20 and $-80{ }^{\circ} \mathrm{C}$ in glycerol suspensions supplemented with $60 \%(\mathrm{v} / \mathrm{v})$ natural seawater and $20 \%(\mathrm{v} / \mathrm{v})$ distilled water. For phenotypic comparison, Hirschia baltica DSM 5838 ${ }^{\mathrm{T}}$, Hyphomonas polymorpha DSM $2665^{\mathrm{T}}$, Maricaulis maris DSM $4734^{\mathrm{T}}$ and Oceanicaulis alexandrii DSM $11625^{\mathrm{T}}$ were grown on MA for 5 days at $30{ }^{\circ} \mathrm{C}$.

The isolation of chromosomal DNA and the amplification of the $16 \mathrm{~S}$ rRNA gene sequence by PCR were carried out as described elsewhere (Lee, 2007). The PCR product was purified from unincorporated primer oligonucleotides using the Wizard PCR Preps DNA Purification System (Promega). The PCR products were sequenced using an ABI PRISM BigDye Terminator cycle sequencing kit (Applied Biosystems) and an automatic DNA sequencer (3730xl; Applied Biosystems). A partial 16S rRNA gene sequence (1328 bp) of strain GSW $-23^{\mathrm{T}}$ was subjected to a preliminary BLAST search against the GenBank database, revealing that strain GSW-23 ${ }^{\mathrm{T}}$ was related to members of the family Hyphomonadaceae (class Alphaproteobacteria). CLUSTAL_X software (Thompson et al., 1997) was used to align the corresponding sequences. A phylogenetic tree was constructed with the neighbour-joining method (Saitou \& Nei, 
1987) and the model of Jukes \& Cantor (1969). A bootstrap analysis (Felsenstein, 1985) was performed with 1000 resamplings for assessing the reliability of tree topology.

The neighbour-joining tree (Fig. 1) showed that strain GSW- $23^{T}$ was related to members of the family Hyphomonadaceae and formed a distinct cluster between members of the genus Hyphomonas and Hirschia baltica DSM $5838^{\mathrm{T}}$, with a high bootstrap value of $89 \%$. 16S rRNA gene sequence similarity values between strain GSW$23^{\mathrm{T}}$ and members of the family indicated that members of the genus Hyphomonas (92.5-93.9\%) were the closest relatives. Other members of the family, including Hirschia baltica DSM $5838^{\mathrm{T}}(90.6 \%)$, Robiginitomaculum antarcticum IMCC $3195^{\mathrm{T}}$ (89.7\%), Maricaulis species (89.0$89.8 \%$ ) and Oceanicaulis alexandrii CC116-3 (88.1\%), were more distantly related to strain GSW $-23^{\mathrm{T}}$.

For chemotaxonomic analyses, biomass was obtained from cultures grown in marine broth 2216 (MB; Difco) for 3 days at $30{ }^{\circ} \mathrm{C}$ in a shaking incubator. Ubiquinones were extracted by the method of Minnikin et al. (1984) and identified by HPLC as described by Kroppenstedt (1985). The Sherlock Microbial Identification System version 6 (MIDI) was used to analyse cellular fatty acids according to the manufacturer's instructions. The extraction and preparation of fatty acid methyl esters were performed using cells grown on MA for 5 days at $30{ }^{\circ} \mathrm{C}$. The base

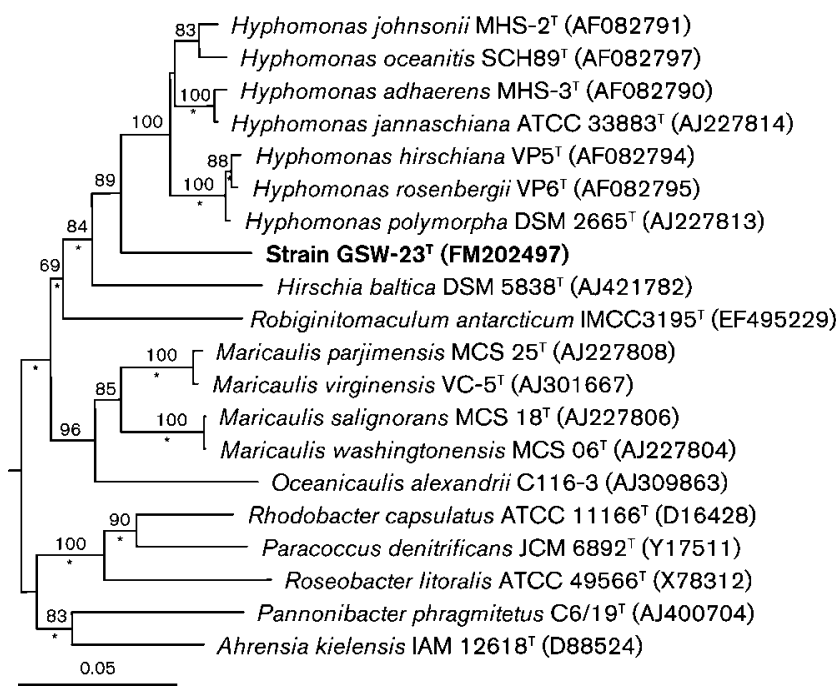

Fig. 1. Neighbour-joining tree constructed with $16 \mathrm{~S}$ rRNA gene sequences, showing the phylogenetic position of strain GSW-23 ${ }^{\top}$ within the family Hyphomonadaceae. Evolutionary distances were computed using the method of Jukes \& Cantor (1969). The sequence of Flavobacterium aquatile ATCC $11947^{\top}$ (GenBank accession no. M62797; not shown) was used as an outgroup. Asterisks indicate nodes that were also recovered in maximumlikelihood and maximum-parsimony analyses. Bootstrap values ( $>50 \%$ ) based on 1000 resamplings are shown at branch nodes. Bar, 0.05 substitutions per nucleotide position. composition of the DNA was determined by HPLC as described by Mesbah et al. (1989).

The cellular fatty acid composition of strain GSW $-23^{\mathrm{T}}$ was represented by considerable amounts of saturated and unsaturated acids (Table 1), with minor proportions of branched and hydroxy acids. The major cellular fatty acids were summed feature 7 (consisting of $\mathrm{C}_{18: 1} \omega 9 c, \mathrm{C}_{18: 1} \omega 12 t$ and/or $\left.\mathrm{C}_{18: 1} \omega 7 c ; 37.1 \%\right), \mathrm{C}_{16: 0}(25.5 \%)$ and $\mathrm{C}_{18: 0}$ $(14.1 \%)$. The major isoprenoid quinone of strain GSW$23^{\mathrm{T}}$ was Q-10 and the DNA G $+\mathrm{C}$ content was $53.3 \mathrm{~mol} \%$, revealing a value intermediate to those of related genera in the family Hyphomonadaceae. The fatty acid compositions of strain GSW $-23^{\mathrm{T}}$ and the type strains of the type species of related genera of the family Hyphomonadaceae are given in Supplementary Table S1 (available in IJSEM Online).

Cell morphology was examined by light microscopy of cultures grown on $\mathrm{MA}$ at $30{ }^{\circ} \mathrm{C}$ for 5 days. Cell suspensions in sterile distilled water were stained using the bioMérieux Gram stain kit according to the manufacturer's directions. Cell motility was observed with an Olympus light microscope equipped with phase-contrast optics $(\times 400$ magnification). The presence of flagella was checked with a transmission electron microscope (1200EXII; JEOL). Colony morphology and pigmentation were observed after 5 days of cultivation at $30{ }^{\circ} \mathrm{C}$ on MA. The cells of strain GSW $-23^{\mathrm{T}}$ were non-budding, motile rods or vibrioids and possessed prosthecae and holdfasts. The elongated cells reproduce by binary fission. A polar flagellum was observed by electron microscopy. A detailed depiction of the typical cellular morphology of strain GSW-23 $3^{\mathrm{T}}$ is given in Fig. 2.

Unless otherwise indicated, phenotypic characteristics were examined on MA as the basal medium. The temperature for growth was tested at $4,10,20,30,37$ and $42{ }^{\circ} \mathrm{C}$. The $\mathrm{pH}$ range for growth was determined on $\mathrm{MA}$ with the $\mathrm{pH}$ adjusted to $\mathrm{pH} 4.1-12.1$ (at intervals of $1.0 \mathrm{pH}$ unit) using $10 \mathrm{M} \mathrm{NaOH}$ and $6 \mathrm{M} \mathrm{HCl}$. Tolerance of various $\mathrm{NaCl}$ concentrations was determined in $\mathrm{MB}$ supplemented with $0,0.5,1,2,3,4,5,6,7,8,9$ and $10 \% \mathrm{NaCl}(\mathrm{w} / \mathrm{v})$. The $\mathrm{OD}_{600}$ of the cell suspension was measured spectrophotometrically at the beginning of the experiment and every day for 5 days. Catalase and oxidase activities were determined using $3 \%(\mathrm{v} / \mathrm{v}) \quad \mathrm{H}_{2} \mathrm{O}_{2}$ and $1 \%(\mathrm{w} / \mathrm{v})$ $N, N, N^{\prime}, N^{\prime}$-tetramethyl-p-phenylenediamine dihydrochloride solutions, respectively. Growth under anaerobic conditions was tested by using the GasPak EZ anaerobe pouch system (BD). Degradation tests were carried out on MA supplemented with $0.5 \%$ colloidal chitin, $0.5 \% \mathrm{CM}-$ cellulose, $0.4 \%$ elastin, $0.4 \%$ hypoxanthine and $0.4 \%$ xanthine. Protease, amylase and tyrosinase activities were determined as described previously (Lee, 2007). Hydrolysis of DNA was tested on MA supplemented with DNase test agar (Difco). The ability to oxidize various substrates as sole carbon sources was tested using GN2 MicroPlates (Biolog) according to the manufacturer's instructions. Other physiological and biochemical properties were tested using API 20NE and API ZYM strips (bioMérieux) 
Table 1. Differential characteristics of strain $\mathrm{GSW}-23^{\top}$ and related genera of the family Hyphomonadaceae

Genera: 1, Ponticaulis gen. nov. (strain GSW-23 ${ }^{\mathrm{T}}$ ); 2, Hirschia (Schlesner et al., 1990); 3, Hyphomonas (Pongratz, 1957; Moore et al., 1984; Weiner et al., 1985, 2000); 4, Maricaulis (Abraham et al., 1999, 2002); 5, Oceanicaulis (Strömpl et al., 2003); 6, Robiginitomaculum (Lee et al., 2007). Members of all genera possess prosthecae. +, Positive; -, negative; v, variable; tr, trace amount ( $<1 \%$ of total); ND, no data available/not detected.

\begin{tabular}{|c|c|c|c|c|c|c|}
\hline Characteristic & 1 & 2 & 3 & 4 & 5 & 6 \\
\hline Shape $^{\star}$ & $R, V$ & $\mathrm{O}, \mathrm{R}$ & $\mathrm{O}, \mathrm{R}$ & $\mathrm{R}, \mathrm{V}$ & $\mathrm{R}, \mathrm{V}$ & $\mathrm{R}, \mathrm{V}$ \\
\hline Flagella & + & + & + & $+\dagger$ & + & - \\
\hline Colony pigmentation $\ddagger$ & $\mathrm{NC}$ & Y & $\mathrm{NC}, \mathrm{G}, \mathrm{RB}$ & $\mathrm{NC}$ & $\mathrm{NC}$ & RO \\
\hline Oxidase & + & ND & + & $\mathrm{ND}$ & + & - \\
\hline Gelatin hydrolysis & + & + & - & - & + & - \\
\hline Optimum temperature $\left({ }^{\circ} \mathrm{C}\right)$ & $30-37$ & $22-28$ & $20-37$ & $20-40$ & 30 & 20 \\
\hline Tolerance of $6 \% \mathrm{NaCl} \$$ & + & - & - & - & + & - \\
\hline \multicolumn{7}{|l|}{ Major fatty acids $(\%) \S$} \\
\hline $\mathrm{C}_{16: 0}$ & 26 & 25 & 6 & 16 & 3 & - \\
\hline $\mathrm{C}_{17: 0}$ & 4 & 2 & 22 & 8 & ND & 14 \\
\hline $\mathrm{i}-\mathrm{C}_{17: 1} \omega 9 c$ & $\mathrm{ND}$ & ND & $\mathrm{ND}$ & 12 & $\mathrm{ND}$ & $\mathrm{ND}$ \\
\hline $\mathrm{C}_{17: 0}$ cyclo & ND & ND & ND & ND & 17 & $\mathrm{ND}$ \\
\hline Summed feature 711 & 37 & 44 & 2 & 29 & 40 & 42 \\
\hline Major quinone(s) & Q-10 & $\mathrm{Q}-10$ & Q-9, Q-10, Q-11, Q-12 & Q-10 & ND & Q-10 \\
\hline DNA G $+C$ content $(\mathrm{mol} \%)$ & 53.3 & 45.6 & $57-62$ & $62.5-65.2$ & 61.8 & 60.3 \\
\hline
\end{tabular}

${ }^{*}$ O, Ovoid; R, rod; v, vibrioid.

$\dagger$ Data for Maricaulis marinus.

\$NC, Colourless; G, grey; RB, reddish brown; RO, rusty orange; Y, yellow.

§Data for Hirschia baltica DSM $5838^{\mathrm{T}}$, Hyphomonas polymorpha DSM $2665^{\mathrm{T}}$, Maricaulis maris DSM $4734^{\mathrm{T}}$ and Oceanicaulis alexandrii DSM $11625^{\mathrm{T}}$ were obtained in this study.

IISummed features represent groups of two or three fatty acids that cannot be separated by the Microbial Identification System. Summed feature 7 consisted of one or more of $\mathrm{C}_{18: 1} \omega 9 c, \mathrm{C}_{18: 1} \omega 12 t$ and $\mathrm{C}_{18: 1} \omega 7 c$.

according to the manufacturer's instructions. The results of physiological and biochemical tests are shown in Table 1 and in the species description.

Members of the family Hyphomonadaceae can be divided into two groups according to their life cycle. One group consists of the genera Hyphomonas and Hirschia and reproduces by means of budding, while the other group contains the genera Maricaulis, Oceanicaulis and Robiginitomaculum and reproduces by binary fission. Strain GSW-23 $3^{\mathrm{T}}$ was similar to the latter group but differed from its members by the optimum temperature range for growth and in some chemotaxonomic characters (i.e. DNA G $+\mathrm{C}$ contents and cellular fatty acid profiles) and also exhibited 16S rRNA gene sequence similarity of less than $90 \%$ to members of the group. As well as the genera Hyphomonas and Hirschia differing from strain $\mathrm{GSW}-23^{\mathrm{T}}$ in their means of reproduction, the genus Hyphomonas differed from strain GSW- $23^{\mathrm{T}}$ in some physiological properties (gelatin liquefaction and tolerance of $6 \% \mathrm{NaCl}$ ) and chemotaxonomic features (major fatty acids, major quinones and DNA $\mathrm{G}+\mathrm{C}$ contents). The genus Hirschia can be distinguished from strain GSW $-23^{\mathrm{T}}$ by its colony pigmentation, different optimum temperature range for growth, lack of tolerance of $6 \% \mathrm{NaCl}$ and not having $\mathrm{C}_{18: 0}$ as a predominant fatty acid. The DNA $\mathrm{G}+\mathrm{C}$ content of the type strain of the type species of the genus Hirschia was $45.6 \mathrm{~mol} \%$, which is considerably lower than that of strain GSW $-23^{\mathrm{T}}$ (53.3 mol\%). The differential features of strain GSW $-23^{\mathrm{T}}$ and related genera of the family Hyphomonadaceae are given in Table 1.

Based on the data from phenotypic and phylogenetic analyses, strain GSW-23 ${ }^{\mathrm{T}}$ represents a novel genus and species in the family Hyphomonadaceae, for which the name Ponticaulis koreensis gen. nov., sp. nov. is proposed.

\section{Description of Ponticaulis gen. nov.}

Ponticaulis (Pon.ti.cau'lis. L. neut. n. pontus the sea; L. masc. n. caulis a stalk, referring to a prostheca; N.L. masc. n. Ponticaulis stalk from the sea). 


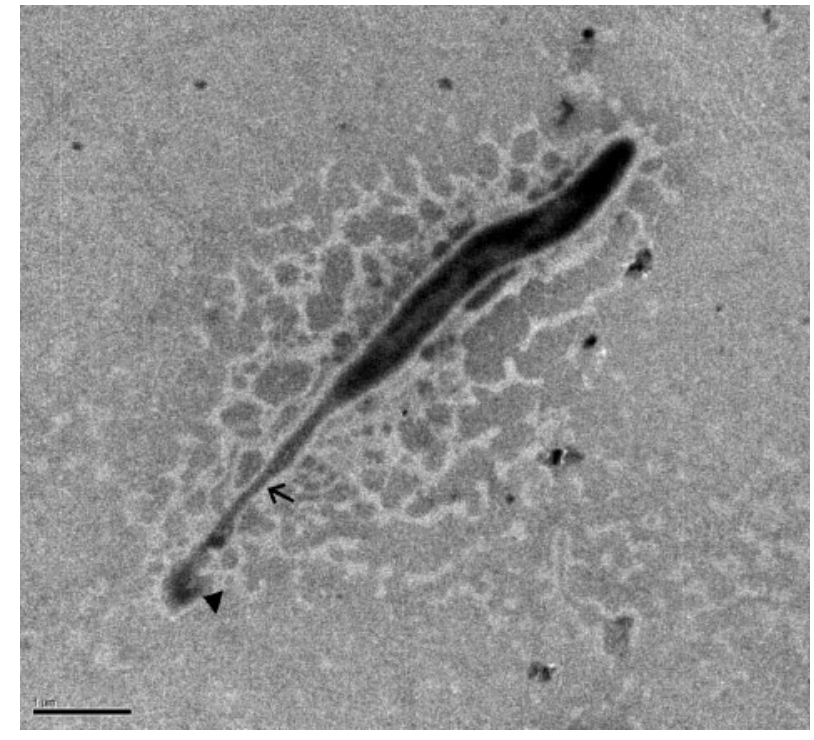

Fig. 2. Transmission electron micrograph of a cell of strain GSW$23^{\top}$ possessing a prostheca (arrow) and a holdfast (triangle). Bar, $1 \mu \mathrm{m}$.

Cells are strictly aerobic, Gram-negative, non-spore-forming, non-budding, obligately halophilic rods or vibrioids that are motile by means of a polar flagellum. Multiplication occurs by binary fission. Some cells possess a long prostheca $(0.2 \mu \mathrm{m}$ in diameter $)$ and a holdfast. The major isoprenoid quinone is Q-10. The major cellular fatty acids are summed feature $7\left(\mathrm{C}_{18: 1} \omega 9 c, \mathrm{C}_{18: 1} \omega 12 t\right.$ and/or $\left.\mathrm{C}_{18: 1} \omega 7 c\right), \mathrm{C}_{16: 0}$ and $\mathrm{C}_{18: 0}$. The genus belongs phylogenetically to the family Hyphomonadaceae in the class Alphaproteobacteria. The type species is Ponticaulis koreensis.

\section{Description of Ponticaulis koreensis sp. nov.}

Ponticaulis koreensis (ko.re.en'sis. N.L. masc. adj. koreensis pertaining to Korea, where the type strain was isolated).

Exhibits the following properties in addition to those described in the genus. Cells are 3.1-6.6 $\mu \mathrm{m}$ long and 0.4$0.5 \mu \mathrm{m}$ wide. Colonies are colourless, circular, smooth, convex and $0.3-0.5 \mathrm{~mm}$ in diameter after 5 days of incubation. Growth occurs at $10-42{ }^{\circ} \mathrm{C}$ (optimum 30 $37^{\circ} \mathrm{C}$ ), at $\mathrm{pH}$ 6.1-10.1 (optimum $\mathrm{pH}$ 7.1) and with up to $6 \%(\mathrm{w} / \mathrm{v}) \mathrm{NaCl}$. Hydrolyses DNA but not casein or starch. Degrades DL-tyrosine but not elastin, chitin, cellulose, hypoxanthine or xanthine. Positive for gelatin hydrolysis but negative for nitrate reduction, indole production, glucose fermentation, arginine dihydrolase, urease, aesculin degradation and $\beta$-galactosidase (API 20NE). In API ZYM tests, positive for alkaline phosphatase, esterase (C4) (weak), esterase lipase (C8) (weak), leucine arylamidase, trypsin, $\alpha$-chymotrypsin, acid phosphatase and naphtholAS-BI-phosphohydrolase, but negative for lipase (C14), valine arylamidase, cystine arylamidase, $\alpha$ - and $\beta$-galacto- sidase, $\beta$-glucuronidase, $\alpha$ - and $\beta$-glucosidase, $N$-acetyl- $\beta$ glucosaminidase, $\alpha$-mannosidase and $\alpha$-fucosidase. In GN2 MicroPlates, metabolizes Tweens 40 and 80, raffinose, methyl pyruvate, monomethyl succinate, $\beta$ - and $\gamma$-hydroxybutyric acid, $\alpha$-ketoglutaric acid, succinic acid, bromosuccinic acid, L-alaninamide, L-alanine, L-alanyl glycine, Laspartic acid, L-glutamic acid, glycyl L-glutamic acid, Lproline and L-pyroglutamic acid as sole carbon and energy sources, but not $\alpha$-cyclodextrin, dextrin, glycogen, $N$-acetylD-galactosamine, $\mathrm{N}$-acetyl-D-glucosamine, adonitol, L-arabinose, D-arabitol, cellobiose, i-erythritol, D-fructose, Lfucose, D-galactose, gentiobiose, $\alpha$-D-glucose, myo-inositol, $\alpha$-lactose, lactulose, maltose, D-mannitol, D-mannose, melibiose, methyl $\beta$-D-glucoside, D-psicose, L-rhamnose, Dsorbitol, sucrose, trehalose, turanose, xylitol, acetic acid, cis-aconitic acid, citric acid, formic acid, D-galactonic acid lactone, D-galacturonic acid, D-gluconic acid, D-glucosaminic acid, D-glucuronic acid, $\alpha$-hydroxybutyric acid, $p$ hydroxyphenylacetic acid, itaconic acid, $\alpha$-ketobutyric acid, $\alpha$-ketovaleric acid, DL-lactic acid, malonic acid, propionic acid, quinic acid, D-saccharic acid, sebacic acid, succinamic acid, glucuronamide, D-alanine, L-asparagine, glycyl Laspartic acid, L-histidine, hydroxy-L-proline, L-leucine, Lornithine, L-phenylalanine, D- or L-serine, L-threonine, DLcarnitine, $\gamma$-aminobutyric acid, urocanic acid, inosine, uridine, thymidine, phenylethylamine, putrescine, 2-aminoethanol, 2,3-butanediol, glycerol, $\alpha$-DL-glycerol phosphate, $\alpha$-D-glucose 1-phosphate or D-glucose 6-phosphate. The DNA G + C content of the type strain is $53.3 \mathrm{~mol} \%$.

The type strain, GSW $-23^{\mathrm{T}}\left(=\right.$ KCTC $22146^{\mathrm{T}}=\mathrm{DSM} 19734^{\mathrm{T}}$ $\left.=\mathrm{JCM} 14975^{\mathrm{T}}\right)$, was isolated from seawater taken from Kymnyeong Beach on the island of Jeju, Republic of Korea.

\section{Acknowledgements}

This work was supported by the 21C Frontier Microbial Genomics and Application Center Program, Ministry of Science \& Technology, Republic of Korea. We are thankful to Dr R. Pukall for providing the type strains of Hirschia baltica, Hyphomonas polymorpha, Maricaulis maris and Oceanicaulis alexandrii.

\section{References}

Abraham, W. R., Strömpl, C., Meyer, H., Lindholst, S., Moore, E. R., Christ, R., Vancanneyt, M., Tindall, B. J., Bennasar, A. \& other authors (1999). Phylogeny and polyphasic taxonomy of Caulobacter species. Proposal of Maricaulis gen. nov. with Maricaulis maris (Poindexter) comb. nov. as the type species, and emended description of the genera Brevundimonas and Caulobacter. Int J Syst Bacteriol 49, 1053-1073.

Abraham, W. R., Strömpl, C., Bennasar, A., Vancanneyt, M., Snauwaert, C., Swings, J., Smit, J. \& Moore, E. R. B. (2002). Phylogeny of Maricaulis Abraham et al. 1999 and proposal of Maricaulis virginensis sp. nov., $M$. parjimensis sp. nov., $M$. washingtonensis sp. nov. and M. salignorans sp. nov. Int J Syst Evol Microbiol 52, 2191-2201.

Felsenstein, J. (1985). Confidence limits on phylogenies: an approach using the bootstrap. Evolution 39, 783-791. 
Jukes, T. H. \& Cantor, C. R. (1969). Evolution of protein molecules. In Mammalian Protein Metabolism, vol. 3, pp. 21-132. Edited by H. N. Munro. New York: Academic Press.

Kroppenstedt, R. M. (1985). Fatty acid and menaquinone analysis of actinomycetes and related organisms. In Chemical Methods in Bacterial Systematics (Society for Applied Bacteriology Technical Series vol. 20), pp. 173-199. Edited by M. Goodfellow \& D. E. Minnikin. New York: Academic Press.

Lee, S. D. (2007). Tamlana crocina gen. nov., sp. nov., a marine bacterium of the family Flavobacteriaceae isolated from beach sediment in Korea. Int J Syst Evol Microbiol 57, 764-769.

Lee, K. B., Liu, C. T., Anzai, Y., Kim, H., Aono, T. \& Oyaizu, H. (2005), The hierarchical system of the 'Alphaproteobacteria': description of Hyphomonadaceae fam. nov., Xanthobacteraceae fam. nov. and Erythrobacteraceae fam. nov. Int J Syst Evol Microbiol 55, 1907-1919.

Lee, K., Lee, H. K., Choi, T.-H. \& Cho, J.-C. (2007). Robiginitomaculum antarcticum gen. nov., sp. nov., a member of the family Hyphomonadaceae, from Antarctic seawater. Int $J$ Syst Evol Microbiol 57, 2595-2599.

Mesbah, M., Premachandran, U. \& Whitman, W. B. (1989). Precise measurement of the $\mathrm{G}+\mathrm{C}$ content of deoxyribonucleic acid by high-performance liquid chromatography. Int J Syst Bacteriol 39, 159167.

Minnikin, D. E., O’Donnell, A. G., Goodfellow, M., Alderson, G., Athalye, M., Schaal, A. \& Parlett, J. H. (1984). An integrated procedure for the extraction of bacterial isoprenoid quinones and polar lipids. J Microbiol Methods 2, 233-241.

Moore, R. L., Weiner, R. M. \& Gebers, R. (1984). Genus Hyphomonas Pongratz 1957 nom. rev. emend., Hyphomonas polymorpha Pongratz
1957 nom. rev. emend., and Hyphomonas neptunium (Liefson 1964) comb. nov. emend. (Hyphomicrobium neptunium). Int J Syst Bacteriol 34, 71-73.

Pongratz, E. (1957). D'une bactérie pédiculée isolée d'un pus de sinus. Schweiz Z Pathol Bakteriol 20, 593-608 (in French).

Saitou, N. \& Nei, M. (1987). The neighbor-joining method: a new method for reconstructing phylogenetic trees. Mol Biol Evol 4, 406425.

Schlesner, H., Bartels, C., Sittig, M., Dorsch, M. \& Stackebrandt, E. (1990). Taxonomic and phylogenetic studies on a new taxon of budding, hyphal Proteobacteria, Hirschia baltica gen. nov., sp. nov. Int J Syst Bacteriol 40, 443-451.

Strömpl, C., Hold, G. N., Lunsdorf, H., Graham, J., Gallacher, S., Abraham, W.-R., Moore, E. R. B. \& Timmis, K. N. (2003). Oceanicaulis alexandrii gen. nov., sp. nov., a novel stalked bacterium isolated from a culture of the dinoflagellate Alexandrium tamarense (Lebour) Balech. Int J Syst Evol Microbiol 53, 1901-1906.

Thompson, J. D., Gibson, T. J., Plewniak, F., Jeanmougin, F. \& Higgins, D. G. (1997). The CLUSTAL_X windows interface: flexible strategies for multiple sequence alignment aided by quality analysis tools. Nucleic Acids Res 25, 4876-4882.

Weiner, R. M., Devine, R. A., Powell, D. M., Dagasan, L. \& Moore, R. L. (1985). Hyphomonas oceanitis sp. nov., Hyphomonas hirschiana sp. nov., and Hyphomonas jannaschiana sp. nov. Int J Syst Bacteriol 35, 237-243.

Weiner, R. M., Melick, M., O'Neill, K. \& Quintero, E. (2000). Hyphomonas adhaerens sp. nov., Hyphomonas johnsonii sp. nov. and Hyphomonas rosenbergii sp. nov., marine budding and prosthecate bacteria. Int J Syst Evol Microbiol 50, 459-469. 